\title{
Design of a System Supporting the Collection of Information on the Completed Didactic Classes at Medical University of Białystok as an Attempt at Improving the Quality of Education
}

\author{
Jarosław Ogonowski ${ }^{1}$, Robert Milewski ${ }^{2}$ \\ 1 IT Department, Medical University of Bialystok, Poland \\ 2 Department of Statistics and Medical Informatics, Medical University of Bialystok, \\ Poland
}

\begin{abstract}
Obtaining a sufficient amount of measurable and reliable results of student surveys has always posed a challenge for university teams tasked with the provision of the quality of education. This is especially visible at faculties where education is based on the classic classroom-based model, which then transfers to clinical units, hospital wards, and specialist laboratories. The highly unpredictable pandemic situation caused by the SARS-CoV-2 virus raises the bar for the evaluation of didactics. Fortunately, the continuous technological progress in the area of Artificial Intelligence makes it possible to design the implementation of tools that would improve the position of systems for the management of courses of studies. The evaluation survey for didactic classes, as one of the last output data obtained during the process, may finally become a fully recognized source of information about the conducted classes and the teachers themselves. On the other hand, it may become a tool for those surveyed to influence the quality of classes, express their opinion, present suggestions and propositions generally pertaining to changes in the process of education. New information technologies not only make it possible to improve the effectiveness of reaching the recipients, but also provide completely new, very reliable methods of acquisition of credible behaviour, used as integration data in solutions based on machine communication. Using Artificial Intelligence coupled with data may make it possible to use intelligent communication for effective management of the process of surveying - a solution that has so far been used in business, in the form of the so-called bots. As a result, this would lead to an ongoing, fully quantitative and qualitative, assessment of classes.
\end{abstract}

\section{Introduction}

The introduction of new rules concerning the quality of education some time ago caused a revolution in Polish universities. Adapting didactics, administration, and the whole of the functioning of universities had been 
preceded by a large amount of work, i.e. implementing new internal legal regulations such as Senate resolutions, Rector regulations, etc. Rector's representatives were appointed whose task was to supervise the quality of education; special teams and committees were created to study the issue. Moreover, accreditation committees adopted control of the provision and improvement of the quality of education at the university as one of the most important criteria of their evaluation process. The third criterion in the general assessment of compliance with the criteria of the programme evaluation of the State Accreditation Committee is "Effectiveness of the internal system for the provision of the quality of education" (Polska Komisja Akredytacyjna, 2021).

One of the elements of the proper functioning of the process of the quality of education as a whole is survey-based assessment of didactic classes. It is one of the many variables that have an impact on the assessment of didactic classes and the persons who conduct them. Results of such surveys have a huge influence on the whole procedure of functioning of the system for the provision and improvement of the quality of education at the university. They are not only useful for statisticians but also directly indicate those aspects that need improvement and expose weak spots of the system's functioning. This is why their existence and, more importantly, completion rate is so important.

Surveying covers all areas of activity of the university, which are interconnected and merge to form a huge single organism which, when functioning efficiently, is the very source of results and guidelines in the area of improvement. During class observations, students, doctoral students, and participants of postgraduate courses have the opportunity to express their opinion about didactic classes in terms of understanding the content, compliance with the schedule, grading criteria, contact with the teacher, and use of didactic materials. They also assess library access, the quality of library resources, and the conditions of education (inventory, access to computers and laboratory equipment). They may also assess the syllabus, express their opinion about exam requirements, the teaching methods, or the attitudes of the teacher. All the elements of assessment concern, separately, practical classes, seminars, and lectures. A separate survey exists that concerns the system of didactic and scientific tutelage. On the other hand, the teachers may express their opinions about the group of students, i.e. they assess their level of preparation for classes, cooperation, and manners. It can be noticed that both systems, i.e. the assessments performed by students and teachers, are interconnected. Hence, reliable and systematic completion of the survey has a huge impact on the quality of education at the university as a whole 
and a huge causative power, i.e. the knowledge it provides makes is possible to change those aspects that do not work properly and improve what may work even more efficiently. Hence, anonymous surveys constitute the source of knowledge about the reality of the functioning of the university. The tool makes it possible for students to truthfully indicate the aspects that they like and those that they do not. A question remains, though: how to persuade the students to complete the survey (Szyjewski, 2018)?

\section{Principles}

The system of student surveying has been functioning at the Medical University of Białystok for over a dozen years. Surveys in the traditional (paper) form completed as validation of didactic classes were one of the tools for the evaluation of student satisfaction with classes and at the same time provided feedback in the form of an assessment of the teacher. Obviously, paper documents, collected by the lecturers at the very beginning, were analysed in the traditional manner. In simple terms, their contents were read and analysed.

In a short time, mainly due to the amount of paper documentation, basic tools for digital processing (mass digitization of documentation) and analysis with the use of widely available applications such as Microsoft Excel were introduced. Survey templates enabled their scanning and automatic representation of results in the form of a spreadsheet. Data format conversion available in the Microsoft application made it possible, in the following steps, to import the data to databases and statistical software. The data was successively collected and archived, forming the support base for the process of periodic assessment of didactic staff.

In the following years, due to its accessibility and undeniable ease of use, the possibility to evaluate classes with the use of surveys filled in electronically, via website-based tools, was introduced. For this purpose, surveying systems distributed on the Free Software basis were implemented in 2011. The explicit objective was to achieve massive returns, thus obtaining a valid source that would provide answers to the questions included in the surveys in a straightforward manner. Furthermore, it was also expected that the possibility to express additional opinions, propositions, suggestions, or criticism, would allow to increase the level of education and the control over it.

The possibility of using the electronic surveying tool was well received both by the staff and students. Unfortunately, in a relatively short time, i.e. as early as at the end of the academic year when the possibility to 
complete the surveys electronically was introduced, the first indications of a lower than expected response rate could be noticed. Earlier, paper surveys had been distributed to students by teachers during the classes. In its simplicity, the traditional "algorithm" was devoid of the time lag resulting from the time needed for completing the survey (it was usually filled in during or immediately after classes), which often determined whether the action was performed or not. The surveys were collected immediately after the classes. The electronic system enabled postponed assessment of classes, including assessment of the teacher. Obviously, the system was made available within the time frames specified in the schedule of classes for a given academic year, excluding the exam sessions. This state of affairs, due to the non-obligatory character of participation in the process of surveying, showed that when an action is not intended to complete, for instance, participation in the classes (in this case, the completion was to take the form of the survey being filled in), the process becomes shorter. The completion of the survey is postponed or not performed at all.

The next observed distinguishing factor, which has an impact on the reduced number of completed surveys, was the emergence of distrust in the anonymous character of the process of surveying itself. It was argued that in the era of electronic systems, there is always a possibility of identification of the person who completed the particular survey. Of course, the system was designed in such a way that it ensured full anonymity of the persons who completed them; the response rate, however, was lower than expected. (Zarządzenie Rektora Uniwersytetu Medycznego w Białymstoku, 2013).

A comparison of response rates for the academic years 2012/2013, 2013/2014, 2014/2015, 2015/2016, and 2016/2017 is presented below, based on a summary of surveys of didactic classes prepared by the University Team for the Provision and Improvement of the Quality of Education. The results cover data from the whole university. For the needs of this paper, the authors believe that presenting the results as the arithmetic average from all the faculties is the most appropriate form.

The mean response rates for the evaluation surveys from the students who participated in didactic classes in the academic years 2012/2013, 2013/2014, 2014/2015, 2015/2016, and 2016/2017 were as follows:

- Academic year 2012/2013 - 10.27\%,

- Academic year 2013/2014 - 15.03\%,

- Academic year 2014/2015 - 15.63\% (UMB, 2021a),

- Academic year 2015/2016 - 18.31\% (UMB, 2021b),

- Academic year 2016/2017 - 20.77\% (UMB, 2021c). 
The above data is averaged. It should be noted, however, that smaller faculties which educate in the classic academic sense are characterized by a higher response rate compared to faculties where a large number of classes is conducted on clinical level (Ostasz et al., 2017).

Statistics concerning the response rate of surveys from doctoral students, on the other hand, need to be mentioned due to the percentage of returned completed surveys. Obviously, in this case the number of doctoral students at the individual faculties translate into the number of returned surveys; it must be emphasized, however, that when expressed in percent, it was much higher, and oscillated around over $30 \%$ in the years $2013 / 2014$, $2014 / 2015$, and $2015 / 2016$. Then, in the year $2016 / 2017$, a drop of $22 \%$, i.e. almost by $1 / 3$, was noted.

In light of the above, the university authorities, together with student organizations, introduced incentives; these included awards for the highest rate of completion. This was well received by the voting members, but improved the statistics only slightly. In the following years, the response rate statistics stabilized at an average level of over a dozen per cent. The academic year 2016/2017 showed some promise, when the average response rate from students of $20 \%$ was exceeded (UMB, 2021c).

Generally, the forecasts assumed a slight increase in the response rate. The IT system also evolved, ensured reliability of operation, and increased the level of trust the students put in the tool.

What doubtlessly interested the faculty teams in terms of the assessment of the quality of education on the basis of student surveys were the negative opinions expressed about those who were the object of the assessment. All the time, a minimum percent response rate from those entitled to complete the particular didactic surveys of $50 \%$ was set as the basis for the partial assessment to be considered part of the total class assessment.

On the one hand, judging by the response rate statistics throughout the years and with the adopted $50 \%$ criterion for negative assessment, it could have been assumed as highly probable that the condition would be extremely difficult to meet. However, the following trend was noticed: e.g., only 2 out of 100 persons entitled to complete the survey did it, both of whom assessed the classes negatively. Such cases encourage to find a solution that would provide a more valid and reliable representation of the quality of the conducted classes.

Unfortunately, a return in the form of the number of surveys completed by students and doctoral students does not form a solid basis for the tool to be used as significant support in such assessments. The response rate of surveys from the last several years clearly shows that still a small number of 
participants of classes complete them. The last two years' experience in the area of the process of education under the conditions caused by the SARSCoV-2 pandemic clearly shows that effective surveying, as a tool for analyses and assessment, is of great importance in times of limited contacts and face-to-face meetings. Encouraging students to participate in the surveying process, and modification of the existing solutions or looking for new ones, IT-based ones in particular, have become essential for maintaining the expected level of response rate.

Considering the issue from the point of view of the improvement of the quality of education, university authorities have no room for manoeuvre. What can be done to improve the quality of education in the expected manner? How to obtain the necessary "data"? To achieve a response, "input" is necessary beforehand, which could take the form of data obtained from surveys provided by those most interested and directly experienced in the surveyed area. As it is, these are still insufficient, which completes the vicious circle. On the one hand, students and doctoral students expect a high quality of services; on the other, they are not willing to use tools in the form of surveys that would enable them to contribute to the maintenance or improvement of the very quality that they expect.

Teams and committees responsible for the system for the provision and improvement of the quality of education analysed the large numbers of surveys completed during the period of over a dozen years' of assessment of classes. This is not enough, however, to treat the results as a valid source that would help to answer the questions as to what and how can be improved in the area of didactics and generally in all the areas students have contact with at the university (Ostasz et al., 2017).

This paper serves as an introduction to the preparation of a study whose tangible effect would be successful encouragement to participate in the process of survey-based assessment of those classes they participate in. This is the first step towards tackling the problem of finding the method that would lead to an increased response rate of surveys.

The survey itself has always been and still is the basic tool used by researchers in the research process as a source that can be mined endlessly when preparing academic papers. The tool, coupled with the researcher's interpretative skills, provides solid bases for various studies and publications as far as content is concerned. Hence, can the student survey also form the basis for studies or should it only be used in the process of evaluation?

Considering the above, the reason for the poor response rate of the surveys needs to be found and a remedy to the situation prepared. What is the source of the "unwillingness" to return a completed survey? Is this the 
simple "I don't want to, I have no time" attitude? If it is, then maybe the questionnaire should be shortened or made more user friendly? Or maybe the content is too complicated? Maybe the format is too illegible? The reasons can be numerous, but what is absolutely certain is that achieving an increased response rate of completed surveys is worth the effort. The valuable knowledge they contain would provide the university with a useful tool for the improvement of the quality of education. In simple terms, the surveys that are expected as the outcome of the study would include answers to all the questions and concerns expressed above. Students, doctoral students, and participants of postgraduate courses know what improvements are needed, therefore it is crucial to make them share the knowledge (Szyjewski, 2018).

The development of IT tools, cloud-based solutions, implementation of the already existing activities on-site, and transforming them into a hybrid form that would become independent from the time and place plot the direction for effective survey-based assessment of didactic classes.

Online educational platforms seem the natural field for implementing survey-based assessment of classes conducted in this manner. Successful integration of solutions present in the already used systems dedicated to the management of courses of studies with surveying systems also constitutes a method for increasing the response rate of surveys.

In the era of modern technologies, which are effectively used in the field of commercial customer services, both in trade and in the service sector, a potential for the development of an AI-based technology whose aim would be to increase the response rate of surveys evaluating didactics can also be recognized. Implementation of solutions focused on mobility and compactness, both of the applications and their content, is another activity intended to be introduced in order to achieve an increased response rate. Creating a system whose format would be adapted to the preferences of the person filling in the data, with a pre-determined content, may prove to be yet another way of meeting the needs of the recipients, i.e. students and doctoral students (Leszczyński et al., 2020; Lindquist, 2018).

The main thread of the study will be the attempt to create and implement AI-based solutions, to be integrated with systems for the management of courses of study and e-learning platforms. The authors intent to create a system that would focus on the function realizing the tasks that would effectively lead the student along the path that ends with a return of the completed survey. The already known rules from task- and conversationoriented solutions will be analysed and used in the evaluation of didactic 
classes. In addition, studies analysing most of the currently known functions used in Artificial Intelligence communication systems, including those focused on conversation, sales, messaging, transferring, or business will be performed. As commercial as this sounds, these are intended for use in software for the management of courses of study (Raport. Polskie Chatboty, 2018).

The following task is to be performed in the planned study: achieving a response rate of surveys at a level that would guarantee their reliable and effective use in the process of evaluation of didactic classes and periodic assessment of the teaching staff. Along the way, the authors intend to achieve an effect in the form of a product to be implemented in IT systems used in the process if management of courses of study. The study will also cover behaviour, including attitudes towards surveys, frequently asked questions about surveys, or the tracking of paths that lead to completing the surveys. Functions of event notifications and further transfer of information about events connected with surveying, which create conditions of technologically comfortable assessment, will also be taken into consideration. Moreover, the possibilities and consequences of combining the aforementioned functions and uses will be tested. All of the above will be performed in order to gain knowledge and, as a result, create a tool for an effective and intelligent AI-based solution using the following technologies: NLP (Natural Language Processing), ML (Machine Learning), or NLU (Natural Language Understanding). An equally large emphasis as that on technology will be put on achieving the effects of the study focusing on the collection of data that would feed the potential application. The commercial, consumer-oriented approach will be employed throughout the study, with focus on profit in the form of response rate (Cichocki, 2021; Chartbots, 2017).

\section{Conclusions}

It is the authors' intention to create a product, i.e. an intelligent assistant, that would accompany students and doctoral students on their path to completing the surveys. This will make the whole procedure easier and more straightforward, taking little time, and encourage them to express their opinions. Above all, though, it will make sure that the process is indeed anonymous. The assistant will be profit-oriented, which is understood solely as maximizing the number of completed surveys evaluating didactics. 
Chartbots 101.(2017). Oracle. Retrieved from: https://www.oracle.com/pl/a/ocom/ docs/chatbot-infographic-3672253.pdf

Cichocki, R. (2021). Rozmowa z robotem: jak chatboty stały się częścią obsługi klienta. Devinti. Retrieved from: https://blog.deviniti.com/pl/freshworks/ chatboty-w-obsludze-klienta/

Leszczyński, P. K., Roszak, M., Binkowska, A., Świniarski, P., Wilk, A., Charuta, A., Zacharuk, T. \& Kononowicz, A. A. (2020). E-learning Practice at Medical Universities in Poland in the Perspective of the SARS-CoV2 Pandemic. Studies in Logic, Grammar and Rhetoric, 64(1), 35-58. doi: $10.2478 /$ slgr-2020-0039

Lindquist, M. (2018). 3 Ways The Next Generation Of Chatbots Will Change Business. Forbes. Retrieved from: https://www.forbes.com/sites/oracle/2018/11/ $12 / 3$-ways-the-next-generation-of-chatbots-will-change-business $/$ ?sh $=24675$ $9 \mathrm{bd} 5920$

Ostasz, G., Woźniak, J., \& Pacana, A. (2017). Badanie satysfakcji studentów z systemu ankietyzacji. Modern Management Review, 24(4), 91-101. doi: 10.7862/ rz.2017.mmr.44

Polska Komisja Akredytacyjna (2021). System Zarządzania Jakością PKA. Retrieved from: https://www.pka.edu.pl/standardy-i-procedury/system-zarza dzania-jakoscia-ksztalcenia/.

Raport. Polskie Chatboty 2018. (2018). Retrieved from: https://www.k2.pl/blog/ raport-polskie-chatboty-2018

Szyjewski, Z. (2018). Metody badania zachowań społecznych. Studia i Prace WNEIZ US, 54(2), 147-162. doi: 10.18276/sip.2018.54/2-10

UMB. (2021a). Wyniki ankietyzacji zajęć dydaktycznych za rok akademicki 2014/2015. Retrieved from: https://www.umb.edu.pl/s,6353/Ankiety

UMB. (2021b). Wyniki ankietyzacji zajęć dydaktycznych za rok akademicki 2015/2016. Retrieved from: https://www.umb.edu.pl/s,6353/Ankiety

UMB. (2021c). Wyniki ankietyzacji zajęć dydaktycznych za rok akademicki 2016/2017. Retrieved from: https://www.umb.edu.pl/s,6353/Ankiety

Zarządzenie Rektora Uniwersytetu Medycznego w Białymstoku. (2013). Zarządzenie nr 13/13 Rektora Uniwersytetu Medycznego w Białymstoku z dnia 04.02.2013 r. w sprawie wprowadzenia Regulaminu Działania Systemu Zapewnienia i Doskonalenia Jakości Kształcenia w Uniwersytecie Medycznym w Białymstoku. Retrieved from: http://oldbip.umb.edu.pl/?app=zarzadzenia $\&$ nid $=750 \& y=2013 \&$ which $=$ Rektora 